\title{
Analisis Korelasi Akurasi, Ketepatan Waktu Dan Relevansi Informasi Terhadap Kepuasan Pemakai Sistem Informasi PT. PERISAI HUSADA
}

\author{
Dudi Pratomo \\ Dosen Tetap Universitas Telkom Bandung \\ e-mail: dudipratomo@yahoo.com \\ Willy. S. Yuliandhari \\ Dosen Tetap Universitas Telkom Bandung \\ e-mail willyyuliandhari@ymail.com
}

\begin{abstract}
The use of information systems that needed by users, must be accurate, timeliness and relevant. Accurate reflect the information must be clearly presented and not biased or miss-understanding, timeliness means that information is a vailable when needed, relevant information is useful for users.

The aim of this research is to analize the correlation between accurate, timeliness and relevant for the satisfaction of user information system, which partially and simultainly. The research method is descriptive verificative, case study at PT. Perisai Husada, with the number of respondens are 30 workers who users of the information system.
\end{abstract}

The results of this recearch prove that accurate information and relevant information have a strong corelation to user satisfaction but timeliness information have a low correlation.

Key words: Accurate, timeliness, relevant information, user satisfaction of information system 


\section{PENDAHULUAN}

\section{Latar Belakang Penelitian}

Kegiatan bisnis yang dilakukan perusahaan dewasa ini memiliki kemajuan yang sangat pesat dan diikuti dengan perkembangan teknologi informasi yang pesat pula. Perkembangan teknologi informasi ini di satu sisi dapat membantu meringankan tugas dan tanggung jawab dari berbagai pihak yang terkait di dalam perusahaan. Kemajuan teknologi yang dicapai perusahaan akan mendorong perusahaan akan penyesuaian kebutuhan akan informasi yang cepat, akurat, relevan, tepat waktu (up to date) dan terintegrasi pada semua bagian, sehingga dapat membantu dalam peningkatan produktivitas dan kinerja perusahaan.

Di dalam suatu perusahaan, sistem informasi yang telah diimplementasikan harus mampu memberikan informasi yang berkualitas bagi para pemakainya dan sesuai dengan kebutuhan pemakainya, agar implementasi sistem informasi tersebut menjadi bermanfaat. Sebaliknya, apabila informasi yang dihasilkan tidak sesuai dengan maksud dan tujuan dari kebutuhan penggunanya, maka kebutuhan akan informasi tersebut menjadi tidak berkualitas. Jika hal ini dapat tercapai, maka dapat dikatakan bahwa tujuan dari sistem informasi tersebut dapat tercapai.

Sistem informasi yang dikelola dan dapat terintegrasi dengan baik akan memberikan suatu keunggulan kompetitif bagi perusahaan yang menerapkannya, khususnya dalam hal peningkatan pelayanan penyediaan informasi kepada para pemakai informasi baik pemakai internal perusahaan maupun pemakai eksternal perusahaan maupun. Penggunaan sistem informasi yang baik akan dapat membantu untuk mempercepat layanan pemrosesan data atau laporan.

Dalam lingkup sistem informasi, kepuasan para pengguna adalah seberapa jauh pengguna percaya pada suatu sistem informasi yang disediakan untuk memenuhi kebutuhan informasi yang mereka perlukan. Jika sistem informasi yang disediakan tidak memberikan kepuasan bagi para penggunanya, maka para pengguna sistem informasi akan mengalami kekecewaan dan mencari alternatif lain. Dengan demikian kepuasan para pengguna dapat digunakan sebagai indikator untuk mengevaluasi kinerja sistem informasi suatu perusahaan (Zunaidi, 2011)

Penelitian ini akan menggunakan objek penelitian di Klinik Spesialis Penyakit Dalam dan Saraf Perisai Husada yang telah mengunakan sistem informasi akuntansi terintegrasi yang dibuat secara custom sesuai kebutuhan di klinik.

\section{Rumusan Masalah}

Berdasarkan latar belakang penelitian yang telah dipaparkan sebelumnya, maka rumusan masalah yang di dalam penelitian ini sebagai berikut

a) Bagaimana akurasi, ketepatan waktu dan relevansi informasi menurut pengguna sistem informasi?

b) Bagaimana korelasi akurasi informasi dan kepuasan pemakai sistem informasi ?

c) Bagaimana korelasi ketepatan waktu dan kepuasan pemakai sistem informasi?

d) Bagaimana korelasi relevansi informasi dan kepuasan pemakai sistem informasi? 


\section{Tujuan Penelitian}

Tujuan penelitian berdasarkan rumusan masalah di atas, adalah sebagai berikut :

a) Untuk mengetahui akurasi, ketepatan waktu dan relevansi informasi menurut pengguna sistem informasi.

b) Untuk mengetahui korelasi akurasi informasi dan kepuasan pemakai sistem informasi .

c) Untuk mengetahui korelasi ketepatan waktu dan kepuasan pemakai sistem informasi.

d) Untuk mengetahui korelasi relevansi informasi dan kepuasan pemakai sistem informasi.

\section{Manfaat atau Kepentingan Penelitian}

a) Aspek Teoritis

Manfaat teoritis yang ingin dicapai dari hasil penelitian ini adalah :

- Bagi Penulis

Penelitian ini diharapkan dapat memberikan tambahan pengetahuan dan wawasan dalam memperdalam mata kuliah Sistem Informasi Akuntansi

- Bagi peneliti yang akan datang

Dapat dijadikan referensi untuk melakukan penelitian selanjutnya

b) Aspek Praktis

Manfaat praktis khususnya bagi perusahaan, adalah :

Bagi Klinik Perisai Husada penelitian ini akan menjadi bahan masukan dan evaluasi dalam pengunaan sistem informasi akuntansi yang telah diterapkan.

\section{Landasan Teori}

\section{Kualitas Informasi}

Nilai informasi ditentukan oleh banyak hal, diantaranya adalah kualitas informasi karena secara tidak langsung nilai informasi akan diperoleh. Berbagai macam karakteristik yang digunakan oleh para ahli dalam mengukur kualitas informasi, mereka mempunyai pemikiran yang berbeda - beda dalam menentukan kualitas informasi. Ahituv yang dikutip oleh Jogiyanto (2007:16), mengukur kualitas informasi dengan menggunakan 5 macam karakteristik yaitu :

1. Akurasi (accuracy)

2. Ketepatwaktuan (timelines)

3. Relevan (relevance)

4. Agregasi (aggregation)

5. Pemformatan (formatting)

Hal yang sama dikemukan oleh Ivari dan Koskela yang dikutip oleh Jogiyanto (2007:17), yang menggunakan tiga buah konstruk untuk mengukur kualitas informasi, yaitu

1. Keinformatifan konstruk (construct informativeness) yang terdiri dari relevansi item, kelengkapan, kekinian, akurasi dan kredibilitas. 
2. Keaksesan (accessibility) terdiri dari kenyamanan, ketepatwaktuan dan interpretabilitas.

\section{Keadaptasian (adaptability)}

Sedangkan Swanson yang dikutip oleh Jogiyanto (2007:16), mengukur kualitas informasi dengan pengukuran keunikan (uniquness), ketepatan (conciseness), kejelasan (clarity) dan keterbacaan (readability) Berdasarkan pendapat dan uraian tentang karakteristik yang digunakan dalan mengukur kualitas informasi dapat dikatakan bahwa kualitas informasi tergantung dari 4 hal yaitu :

1. Akurat (Accurate)

Informasi dikatakan akurat yaitu informasi harus jelas mencerminkan maksud yang disampaikan dan harus bebas dari kesalahan-kesalahan serta tidak bias atau menyesatkan. Ukuran keakuratan informasi amat bervariasi dan amat tergantung pada sifat informasi yang dihasilkan. Semakin kritis suatu informasi, akan semakin tinggi keakuratan yang diperlukan, sehingga semakin tinggi tingkat kepuasan yang diberikan kepada penggunanya.

2. Tepat Waktu (Timelines) Umur informasi merupakan faktor yang kritikal dalam menentukan kegunaanya. Ketepatan adalah informasi tidak lebih tua dari periode waktu tindakan yang didukungnya. Ketepatan waktu juga berarti kegiatan menyajikan informasi pada saat transaksi terjadi atau pada saat informasi tersebut dibutuhkan. Informasi yang terlambat diterima, nilai kegunaannya akan lebih rendah, karena informasi yang cepat dan tepat akan lebih baik

3. Relevan (Relevance) Informasi dikatakan relevan apabila informasi tersebut harus bermanfaat bagi si penerima informasi. Relevansi informasi yang diterima oleh masingmasing penerima sangatlah berbeda-beda.

4. Lengkap (Complete) Lengkap ialah tidak boleh ada bagian informasi yang penting atau esensial bagi pengambil keputusan atau pelaksanaan tugas yang hilang, karena akan menghasilkan keputusan yang salah nantinya.

\section{Sistem Informasi}

Sistem informasi menurut Hall (2007:9) adalah serangkaian prosedur formal di mana data dikumpulkan, diproses menjadi informasi dan didistribusikan ke para pengguna. Menurut Widjanjanto (2001:30) mengatakan bahwa proses pengembangan sistem informasi terdiri dari beberapa tahap, yaitu:

\section{Tahap Perencanaan Sistem}

Pada tahap ini idealnya pengembangan sistem dilaksanakan dalam suatu kerangka rencana induk sistem yang mengkoordinasikan proyek-proyek pengembangan sistem pertama dalam rencana strategis perusahaan.

2. Tahap Analisis Sistem

Adalah proses untuk menguji sistem informasi yang ada berikut dengan 
lingkungannya dengan tujuan untuk memperoleh petunjuk mengenai berbagai kemungkinan perbaikan yang dapat dilakukan untuk meningkatkan kemampuan diri sendiri.

\section{Tahap Desain Sistem}

Dalam tahap ini tim penyusun harus dapat menerjemahkan saran-saran yang dihasilkan dari analisis sistem kedalam bentuk yang dapat diimplementasikan.

4. Tahap Implementasi

Pada tahap ini kegiatan yang paling banyak menyita waktu adalah kegiatan pengujian program komputer yang disebut juga proses pengujian persetujuan. Sedangkan proses akhir dalam tahap ini adalah proses konversi dimana semua data yang disimpan dalam file sistem lama harus dipindahkan ke file dengan format sistem baru.

5. Tahap Operasional Sistem

Setelah berjalan dengan baik sistem baru perlu dipelihara dan terus dievaluasi untuk mengetahui adanya kelemahan-kelemahan tertentu yang mungkin belum terlibat pada tahap-tahap sebelumnya.

\section{Kepuasan pemakai Informasi}

Menggambarkan keselarasan antara harapan dan hasil yang diperoleh dari adanya suatu sistem informasi. Kepuasan pemakai merupakan tingkat kesepadanan antara kebutuhan yang ingin dipenuhi dengan kenyataan yang diterima. Dalam lingkup sistem informasi, kepuasan para pemakai adalah seberapa jauh pemakai percaya pada suatu sistem informasi yang disediakan untuk memenuhi kebutuhan informasi mereka. Salah satu cara penting untuk mengukur tingkat kepuasan dari pengguna sistem informasi tersebut adalah melalui penilaian kualitas informasinya. Jika semakin tinggi tingkat kualitas informasinya maka tingkat kepuasan dari para pengguna informasi akan semakin tinggi. ((Zunaidi, 2011)

\section{Kerangka Pemikiran}

\section{Korelasi akurasi informasi terhadap kepuasan pemakai sistem informasi}

Akurasi berarti informasi yang dihasilkan benar dan tidak memiliki arti ganda, semakin akurat suatu informasi maka informasi itu semakin berguna dan bisa diandalkan untuk mengambil suatu keputusan oleh pengguna, sehingga pengguna puas dengan sistem informasi yang digunakannya.

\section{Korelasi ketepatan waktu informasi terhadap kepuasan pemakai sistem informasi}

Ketepatan waktu yaitu ketersediaan informasi yang terbaru( up to date) ketika dibutuhkan oleh pengguna informasi tersebut untuk mengambil suatu keputusan, sehingga pengguna dapat lebih cepat bertindak dengan informasi yang dimilikinya.

\section{Korelasi relevansi informasi terhadap kepuasan pemakai sistem informasi}

Relevan memiliki arti informasi yang dihasilkan oleh suatu sistem informasi sesuai dengan yang dibutuhkan oleh pengguna untuk mengambilsuatu keputusan, sehingga pengguna puas dengan sistem informasi yang digunkannya. 


\section{Metode Penelitian}

\section{Jenis Penelitian}

Jenis penelitian ini adalah deskriptif, bersifitat studi kasus yang dilakukan di PT. Perisai Husada, tujuan penelitian deskriftif adalah untuk membuat deskripsi, gambaran atau lukisan secara sistematis, faktual, dan akurat mengenai fakta - fakta, sifat serta hubungan antar fenomena yang diselidiki. Metode deskriptif, selain memberikan gambaran terhadap fenomena - fenomena, tetapi juga menerangkan hubungan, membuat prediksi, serta mendapatkan makna dan implikasi dari suatu masalah yang ingin dipecahkan. (nazir dalam rama, 2007: 28)

\section{Operasional variabel}

Tabel 1 Operasional Variabel

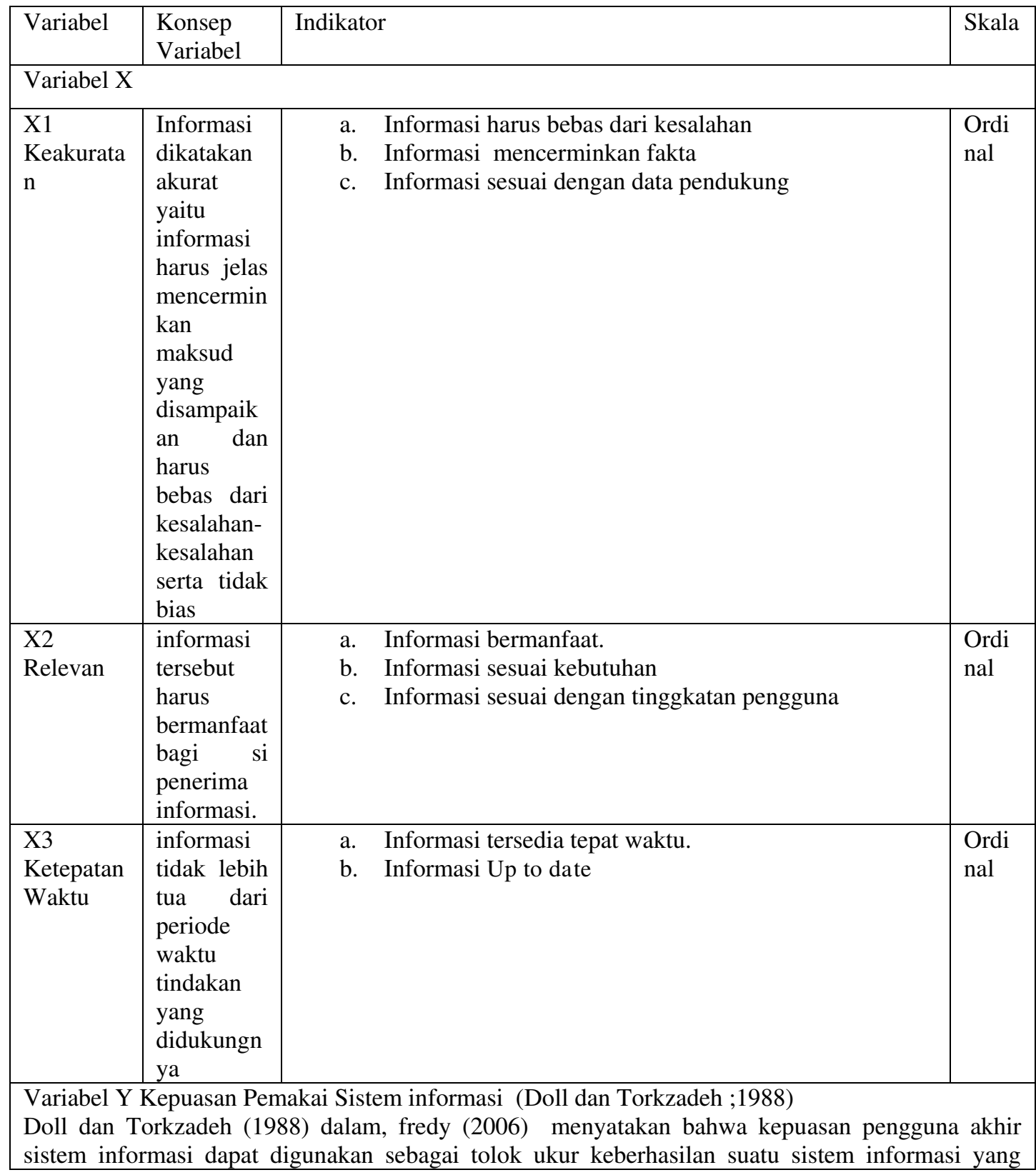




\begin{tabular}{|c|c|c|c|}
\hline Dimensi & $\begin{array}{l}\text { Konsep } \\
\text { dimensi }\end{array}$ & Indikator & Skala \\
\hline $\begin{array}{l}\text { Isi } \\
\text { content })\end{array}$ & $\begin{array}{l}\text { tingkat } \\
\text { kelengkap } \\
\text { an dan } \\
\text { relevansi } \\
\text { informasi } \\
\text { yang } \\
\text { dihasilkan } \\
\text { dengan } \\
\text { kebutuhan } \\
\text { pemakai }\end{array}$ & $\begin{array}{l}\text { 1. } \\
\text { 2. nformasi yang tepat sesuai yang dibutuhkan. } \\
\text { aporan yang sesuai dengan yang dibutuhkan. }\end{array}$ & $\begin{array}{l}\text { ordin } \\
\text { al }\end{array}$ \\
\hline $\begin{array}{l}\text { Keakurata } \\
\mathrm{n} \\
\text { (accuracy) }\end{array}$ & $\begin{array}{l}\text { tingkat } \\
\text { keakuratan } \\
\text { dari } \\
\text { informasi } \\
\text { yang } \\
\text { dihasilkan }\end{array}$ & 1. kurat dalam memberikan informasi yang dibutuhkan. & $\begin{array}{l}\text { ordin } \\
\text { al }\end{array}$ \\
\hline $\begin{array}{l}\text { Bentuk } \\
\text { (format) }\end{array}$ & $\begin{array}{l}\text { bentuk } \\
\text { atau } \\
\text { tampilan } \\
\text { pengguna } \\
\text { telah } \\
\text { sesuai } \\
\text { dengan } \\
\text { kebutuhan } \\
\text { pengguna. }\end{array}$ & $\begin{array}{l}\text { 1. } \\
\text { 2. aporan yang dihasilkan sangat bagus (berguna). } \\
\text { nformasi yang dihasilkan sangat mudah dimengerti (jelas) }\end{array}$ & $\begin{array}{l}\text { ordin } \\
\text { al }\end{array}$ \\
\hline $\begin{array}{l}\text { Kemudah } \\
\text { an } \\
\text { mengguna } \\
\text { kan (easy } \\
\text { of use) }\end{array}$ & $\begin{array}{l}\text { tingkat } \\
\text { kemudaha } \\
\mathrm{n} \quad \text { dalam } \\
\text { pengisian } \\
\text { dan } \\
\text { penggunaa } \\
\mathrm{n} \\
\text { pengguna }\end{array}$ & $\begin{array}{l}\text { 1. } \\
\text { 2. udah digunakan. } \\
\text { udah dimengerti (user friendly) }\end{array}$ & $\begin{array}{l}\text { ordin } \\
\text { al }\end{array}$ \\
\hline $\begin{array}{l}\text { Ketepatan } \\
\text { (time } \\
\text { liness) }\end{array}$ & $\begin{array}{l}\text { informasi } \\
\text { yang } \\
\text { diperoleh } \\
\text { dapat } \\
\text { segera } \\
\text { digunakan } \\
\text { sesuai } \\
\text { kebutuhan } \\
\text { pengguna }\end{array}$ & $\begin{array}{l}\text { 1. } \\
\text { 2. enghasilkan informasi yang dibutuhkan secara tepat waktu } \\
\text { emberikan informasi yang terkini (up to date) }\end{array}$ & $\begin{array}{l}\text { ordin } \\
\text { al }\end{array}$ \\
\hline
\end{tabular}

\section{Tahapan Penelitian}

Langkah pertama yang dilakukan penulis adalah menentukan bidang kajian atau ruang lingkup penelitian, judul penelitian, pemilihan pokok masalah, merumuskan masalah penelitian, dan tujuan penelitian.

Langkah kedua adalah menentukan variabel penelitian, penulis menggunakan faktor-faktor yang mempengaruhi persepsi kepuasaan penggunaan sistem informasi yang didasarkan pada 
instrumen yang dikembangkan oleh Torzakdeh \& doll yaang terdiri atas penilaian isi, keakuratan, bentuk, kemudahan dalam penggunaan dan ketepatan waktuan.

Langkah ketiga melakukan wawancara dan penyebaran kuesioner agar memperoleh data primer serta data kualitatif dan kuantitatif untuk dikelompokkan, diolah, dan dianalisis untuk menentukan persepsi tingkat kepuasan pemakai sistem informasi dan langkah terakhir adalah menguji validitas, reabilitas dan melakukan analisis korelasi.

Langkah keempat adalah memberikan kesimpulan terhadap hasil penelitian untuk menjawab masalah penelitian dan saran kepada perusahaan dalam rangka kemajuan kinerja perusahaan.

\section{Populasi dan Sample}

Sugiyono (2004:72) Populasi yaitu "wilayah generalisasi yang terdiri atas: obyek/ subyek yang mempunyai kualitas dan karakteristik tertentu yang ditetapkan oleh peneliti untuk dipelajari dan kemudian ditarik kesimpulannya. Dalam penelitian ini populasi yang digunakan sebagai objek penelitian adalah karyawan atau pegawai PT. Perisai Husada khususnya yang berhubungan dengan sistem informasi.

Sedangkan dalam teknik pengambilan sampling digunakan nonprobability sampling yakni teknik pengambilan sampel yang tidak memberikan peluang/ kesempatan sama bagi setiap unsur atau anggota populasi untuk dijadikan sampel. Dalam hal ini teknik sampel yang digunakan adalah sampling jenuh yakni penentuan sampel bila semua anggota populasi digunakan sebagai sampel. Hal ini dilakukan karena jumlah populasi relatif kecil berjumlah 30 responden.

\section{Uji Validitas dan Reliabilitas}

Uji validitas dan reliabilitas alat ukur dilakukan untuk memastikan instrumen tersebut merupakan alat ukur yang akurat dan dapat dipercaya. Validitas menjelaskan sejauh mana suatu alat ukur itu mengukur apa yang ingin diukur. Sedangkan reliabilitas menunjukan sejauh mana suatu hasil pengukuran relatif konsisten apabila pengukuran terhadap aspek yang sama pada alat ukur yang sama. Dalam melakukan uji validitas ini digunakan alat analisis korelasi dengan metode korelasi rank spearman dengan alat spss versi 20

Dalam melakukan uj reliabilitas ini menggunakan ketentuan berdasarkan nilai Cronbach's Alpha $(\alpha)$. Hal ini dikarenakan dikarenakan nilai uji reliabity test layak digunakan sebagai instrumen penelitian bila Cronbach's Alpha $(\alpha)$ minimal sebesar 0,7 Dalam pengerjaan pengukuran uji validitas dan reliabilitas instrument penelitian ini digunakan bantuan program SPSS for windows version 20 (Statistic Program for Social Science).

\section{Analisis Deskriptif}

Dalam penelitian ini, peneliti menggunakan tabel frekuensi dan persentase yang bertujuan untuk memberikan gambaran dengan mudah dalam membandingkan atau untuk mengetahui data yang terbanyak. Kemudian data yang telah diolah disimpulkan menggunakan teknik analisis Rank-Order Mean, yaitu garis skala tingkat penilaian persepsi dan ekspektasi (Zikmund dalam Monivia (2010). Alat analisis data ini disajikan dengan menggunakan garis skala. Kriteria persentase garis skala pengukuran pada penelitian ini adalah sebagai berikut : 
Dudi Pratomo

Willy. S. Yuliandhari
Jurnal Manajemen Bisnis Indonesia

Vol. 1, Nomor 3, Juni 2014

Tabel 2

Kriteria Presentasi skor tanggapan responden terhadap skor ideal

\begin{tabular}{|c|c|}
\hline Persentase & Kriteria \\
\hline $20 \%-36 \%$ & Sangat Tidak Baik \\
\hline$>36 \% \cdot 52 \%$ & Tidak Baik \\
\hline$>52 \% \cdot 68 \%$ & Netral \\
\hline$>68 \% \cdot 84 \%$ & Baik \\
\hline$>84 \% \cdot 100 \%$ & Sangat Baik \\
\hline
\end{tabular}

\section{Analisis Korelasi}

Untuk mengetahui hubungan akurasi, ketepatan waktu dan relevansi informasi terhadap kepuasaan pemakai sistem informasi berdasarkan jawaban dari koesioner maka digunakan korelasi Rank Spearman yakni dengan memberikan rangking pada setiap jumlah bobot jawaban dari responden dari setiap pertanyaan pada variabel $\mathrm{X}$ maupun variabel $\mathrm{Y}$.

Setelah diperoleh hasil perhitungan koefisien korelasi dari semua varibel baik varibel $\mathrm{X}$ maupun variabel Y maka selanjutnya ditentukan interpretasi nilai koefisien korelasi. Hal ini bertujuan untuk mengetahui kuat tidaknya hubungan antara variabel $\mathrm{X}$ dengan variabel $\mathrm{Y}$.

Tabel 3

\section{Interpretasi Nilai Koefisien Korelasi}

\begin{tabular}{|l|l|l|}
\hline No & Koefisien Korelasi & Interpretasi \\
\hline 1 & $0,00-0,199$ & Sangat Rendah \\
\hline 2 & $0,20-0,399$ & Rendah \\
\hline 3 & $0,40-0,599$ & Sedang \\
\hline 4 & $0,60-0,799$ & Kuat \\
\hline 5 & $0,80-1,000$ & Sangat Kuat \\
\hline
\end{tabular}

(Sumber: Sugiyono 2004:183)

Selanjutnya dalam hal pengujian hipotesis penelitian ini hasil perhitungan korelasi yang telah dijelaskan di atas langsung dibandingkan dengan rho tabel. Hal ini dikarenakan jenis hipotesis dalam penelitian ini adalah hipotesis asosiatif (hubungan) dengan populasi atau sampel yang digunakan 30 responden. Oleh karena itu dari perhitungan korelasi dapat langsung diambil kesimpulan apakah Ho diterima atau ditolak. Hal ini dilakukan dengan membandingkan nilai koefiasian korelasi rho $(\rho)$ hitung dengan nilai kritis dari rho $(\rho)$ tabel. Kriteria untuk menentukan diterima atau ditolaknya hipotesis yang diajukan adalah sebagai berikut :

Apabila $\rho$ hitung $<\rho$ tabel, maka Ho diterima dan Ha ditolak.

Apabila $\rho$ hitung $>\rho$ tabel, maka Ho ditolak dan Ha diterima.

Hipotesis yang akan diuji menunjukan adanya arah dari hubungan yang akan dihitung. Oleh karena itu pengujian hipotesis ini menggunakan uji dua pihak. Tingkat signifikan yang akan digunakan adalah $0,05(\alpha=0,05)$ hal ini dilakukan karena tingkat signifikan ini sudah umum 
dipakai dalam penelitian ilmu sosial dan cukup ketat untuk mewakili hubungan antara kedua variabel

\section{HASIL PENELITIAN DAN PEMBAHASAN}

Penelitian ini dianalisis dengan menggunakan teknik analisis Rank-Order Mean, dimana data yang dgunakan adalah data ordinal dengan skala likert, yang kemudian akan dipaparkan dalam garis skala untuk melihat posisi tingkat masing-masing akurasi, ketepatan waktu, dan relevansi dari informasi dan kepuasan pemakai sistem informasi PT. Perisai Husada.

\section{Tingkat akurasi, ketepatan waktu, dan relevansi informasi}

Berikut ini adalah analisis mengenai komponen sistem informasi yang diukur dengan menggunakan tingkat keakuratan informasi, ketepatan waktu informasi, dan relevansi informasi.

\section{Tingkat kualitas informasi Berdasarkan Keakuratan Informasi}

\section{Tabel 4}

Tingkat Kualitas Informasi Berdasarkan Dimensi Akurasi Informasi

\begin{tabular}{|c|c|c|c|c|c|c|}
\hline $\begin{array}{c}\text { Item } \\
\text { Pernyataan }\end{array}$ & Jawaban & Skor & $\mathbf{F}$ & $\%$ & $\begin{array}{c}\text { Skor } \\
\text { Aktual }\end{array}$ & $\begin{array}{l}\text { Skor } \\
\text { Ideal }\end{array}$ \\
\hline \multirow{5}{*}{1} & Sangat Setuju & 5 & 20 & 67 & 100 & \multirow{5}{*}{150} \\
\hline & Setuju & 4 & 10 & 33 & 40 & \\
\hline & Netral & 3 & 0 & & & \\
\hline & Tidak Setuju & 2 & 0 & & & \\
\hline & Sangat Tidak Setuju & 1 & 0 & & & \\
\hline \multirow{2}{*}{\multicolumn{5}{|c|}{ Skor Aktual }} & 140 & \\
\hline & & & & & \multicolumn{2}{|l|}{$93,33 \%$} \\
\hline $\begin{array}{c}\text { Item } \\
\text { Pernyataan } \\
\end{array}$ & Jawaban & Skor & $\mathbf{F}$ & $\%$ & $\begin{array}{c}\text { Skor } \\
\text { Aktual }\end{array}$ & $\begin{array}{l}\text { Skor } \\
\text { Ideal }\end{array}$ \\
\hline \multirow{5}{*}{2} & Sangat Setuju & 5 & 21 & 70 & 105 & \multirow{5}{*}{150} \\
\hline & Setuju & 4 & 9 & 30 & 36 & \\
\hline & Netral & 3 & 0 & & & \\
\hline & Tidak Setuju & 2 & 0 & & & \\
\hline & Sangat Tidak Setuju & 1 & 0 & & & \\
\hline & Total & & 30 & 100 & 141 & \\
\hline \multicolumn{5}{|c|}{ Skor Aktual } & \multicolumn{2}{|l|}{$94 \%$} \\
\hline $\begin{array}{c}\text { Item } \\
\text { Pernyataan }\end{array}$ & Jawaban & Skor & $\mathbf{F}$ & $\%$ & $\begin{array}{c}\text { Skor } \\
\text { Aktual }\end{array}$ & $\begin{array}{l}\text { Skor } \\
\text { Ideal }\end{array}$ \\
\hline \multirow{5}{*}{3} & Sangat Setuju & 5 & 19 & 63,3 & 95 & \multirow{5}{*}{150} \\
\hline & Setuju & 4 & 7 & 23,3 & 28 & \\
\hline & Netral & 3 & 4 & 13,4 & 12 & \\
\hline & Tidak Setuju & 2 & 0 & & & \\
\hline & Sangat Tidak Setuju & 1 & 0 & & & \\
\hline \multirow{2}{*}{\multicolumn{5}{|c|}{ Skor Aktual }} & 135 & \\
\hline & & & & & \multicolumn{2}{|c|}{$90 \%$} \\
\hline & \multicolumn{4}{|c|}{ Total Keseluruhan } & \multirow{2}{*}{\multicolumn{2}{|c|}{\begin{tabular}{r|r} 
& 450 \\
$92,44 \%$
\end{tabular}}} \\
\hline & \multicolumn{4}{|c|}{$\%$ Total Keseluruhan } & & \\
\hline
\end{tabular}


Persentase skor tanggapan responden (\% keseluruhan) terhadap dimensi akurasi informasi berdasarkan kepuasan pemakai sistem informasi PT. Perisai Husada dapat dilihat berdasarkan perhitungan di bawah ini :

$\%$ Skor Aktual $=\frac{\text { Total skor }}{\text { Total skor ideal }} \times 100 \%$

Keterangan :

a. Skor aktual adalah jawaban seluruh responden atas kuesioner yang telah diajukan.

b. Skor ideal adalah skor atau bobot tertinggi atau semua responden diasumsikan memilih jawaban dengan skor tertinggi.

Hasil tanggapan responden pada item pertanyaan nomor 1 (satu), yaitu mengenai harus terbebasnya informasi dari kesalahan, tidak bias dan tidak menyesatkan, menghasilkan skor aktual sebesar 140 atau sekitar 93,33 \% dari total skor ideal yang telah ditentukan. Berdasarkan hasil persentase skor aktual untuk item pertanyaan nomor 1 (satu) dapat disimpulkan bahwa tanggapan responden berada pada kategori sangat baik. Hal ini dapat diartikan bahwa para karyawan PT. Perisai Husada menginginkan bahwa informasi yang dihasilkannya harus benar, tidak bias, dan tidak menyesatkan.

Hasil tanggapan responden pada item pertanyaan nomor 2 (dua), yaitu mengenai harus sesuainya informasi dengan fakta yang terjadi atau mencerminkan keadaan yang sebenarnya, menghasilkan skor aktual sebesar 141 atau sekitar $94 \%$ dari total skor ideal yang telah ditentukan. Berdasarkan hasil persentase skor aktual untuk item pertanyaan nomor 2 (dua) dapat disimpulkan bahwa tanggapan responden berada pada kategori sangat baik. Hal ini dapat diartikan bahwa para karyawan PT. Perisai Husada mengetahui bahwa informasi yang dihasilkannya harus mencerminkan keadaan yang sebenarnya.

Hasil tanggapan responden pada item pertanyaan nomor 3 (tiga), yaitu bahwa informasi harus mencerminkan makna yang disertai dengan data pendukungnya, menghasilkan skor aktual sebesar 135 atau sekitar $90 \%$ dari total skor ideal yang telah ditentukan. Berdasarkan hasil persentase skor aktual untuk item pertanyaan nomor 3 (tiga) dapat disimpulkan bahwa tanggapan responden berada pada kategori sangat baik. Hal ini dapat diartikan bahwa para karyawan PT. Perisai Husada mengetahui bahwa informasi yang dihasilkannya (baik keuangan maupun non keuangan) harus terkandung di dalam data pendukungnya.

Berdasarkan ketiga item pernyataan di atas, diperoleh total skor tanggapan responden yang menghasilkan persentase sebesar 92,44\%, maka dapat dinilai bahwa tingkat keakuratan terhadap kepuasan informasi berada pada kategori sangat baik. Sehingga dapat disimpulkan bahwa tingkat keakuratan informasi terhadap kepuasan pemakai sistem informasi PT. Perisai Husada dinilai sangat baik oleh responden. Hal tersebut dilihat dari persentase yang didapat, yaitu sebesar $92,44 \%$ yang berdasarkan analisis Rank-Order Mean termasuk dalam kategori sangat baik (>84\% - 100\%). Besarnya tingkat persentase keakuratan informasi terhadap kepuasan pemakai sistem informasi PT. Perisai Husada ini menunjukkan bahwa para responden merasa sangat puas dengan keakurasian informasi yang dihasilkan. 


\section{Tingkat kualitas informasi Berdasarkan Relevansi Informasi}

Tabel 5

Tingkat Kualitas Informasi Berdasarkan Relevansi Informasi

\begin{tabular}{|c|c|c|c|c|c|c|}
\hline $\begin{array}{c}\text { Item } \\
\text { Pernyataan }\end{array}$ & Jawaban & Skor & $\mathbf{F}$ & $\%$ & $\begin{array}{c}\text { Skor } \\
\text { Aktual }\end{array}$ & $\begin{array}{l}\text { Skor } \\
\text { Ideal }\end{array}$ \\
\hline \multirow{5}{*}{4} & Sangat Setuju & 5 & 23 & 76,7 & 115 & \multirow{5}{*}{150} \\
\hline & Setuju & 4 & 7 & 23,3 & 28 & \\
\hline & Netral & 3 & 0 & & & \\
\hline & Tidak Setuju & 2 & 0 & & & \\
\hline & Sangat Tidak Setuju & 1 & 0 & & & \\
\hline \multirow{2}{*}{\multicolumn{5}{|c|}{ Skor Aktual }} & 143 & \\
\hline & & & & & \multicolumn{2}{|l|}{$95,33 \%$} \\
\hline $\begin{array}{c}\text { Item } \\
\text { Pernyataan }\end{array}$ & Jawaban & Skor & $\mathbf{F}$ & $\%$ & $\begin{array}{c}\text { Skor } \\
\text { Aktual }\end{array}$ & $\begin{array}{l}\text { Skor } \\
\text { Ideal }\end{array}$ \\
\hline \multirow{5}{*}{5} & Sangat Setuju & 5 & 18 & 60 & 90 & \multirow{5}{*}{150} \\
\hline & Setuju & 4 & 7 & 23,3 & 28 & \\
\hline & Netral & 3 & 3 & 10 & 9 & \\
\hline & Tidak Setuju & 2 & 2 & 6,7 & 4 & \\
\hline & Sangat Tidak Setuju & 1 & 0 & & & \\
\hline & Total & & 30 & & 131 & \\
\hline \multicolumn{5}{|c|}{ Skor Aktual } & \multicolumn{2}{|l|}{$87,33 \%$} \\
\hline $\begin{array}{c}\text { Item } \\
\text { Pernyataan }\end{array}$ & Jawaban & Skor & $\mathbf{F}$ & $\%$ & $\begin{array}{c}\text { Skor } \\
\text { Aktual }\end{array}$ & $\begin{array}{l}\text { Skor } \\
\text { Ideal }\end{array}$ \\
\hline \multirow{5}{*}{6} & Sangat Setuju & 5 & 18 & 60 & 90 & \multirow{5}{*}{150} \\
\hline & Setuju & 4 & 10 & 33,3 & 40 & \\
\hline & Netral & 3 & 2 & 6,7 & 6 & \\
\hline & Tidak Setuju & 2 & 0 & & & \\
\hline & Sangat Tidak Setuju & 1 & 0 & & & \\
\hline \multirow{2}{*}{\multicolumn{5}{|c|}{ Skor Aktual }} & 136 & \\
\hline & & & & & \multicolumn{2}{|l|}{$90,7 \%$} \\
\hline \multicolumn{5}{|c|}{ Total Keseluruhan } & \multirow{2}{*}{\multicolumn{2}{|c|}{\begin{tabular}{rr|r}
410 & 450 \\
& $91,11 \%$ \\
\end{tabular}}} \\
\hline & $\% \mathrm{To}$ & Keselur & & & & \\
\hline
\end{tabular}

Hasil tanggapan responden pada item pertanyaan nomor 1 (satu), yaitu bahwa informasi harus memiliki manfaat bagi para penggunanya, menghasilkan skor aktual sebesar 143 atau sekitar 95,33\% dari total skor ideal yang telah ditentukan. Berdasarkan hasil persentase skor aktual untuk item pertanyaan nomor 1 (satu) dapat disimpulkan bahwa tanggapan responden berada pada kategori sangat baik. Hal ini dapat diartikan bahwa para karyawan PT. Perisai Husada menginginkan bahwa informasi yang dihasilkannya harus memiliki manfaat bagi para penggunanya.

Hasil tanggapan responden pada item pertanyaan nomor 2 (dua), yaitu bahwa informasi harus memberikan kesesuaian dengan output yang akan diselesaikannya, menghasilkan skor aktual sebesar 131 atau sekitar 87,33\% dari total skor ideal yang telah ditentukan. Berdasarkan hasil persentase skor aktual untuk item pertanyaan nomor 2 (dua) dapat disimpulkan bahwa 
tanggapan responden berada pada kategori sangat baik. Hal ini dapat diartikan bahwa informasi yang diperlukan harus sesuai dengan tugas yang diemban oleh masing-masing responden.

Hasil tanggapan responden pada item pertanyaan nomor 3 (tiga), yaitu bahwa informasi harus sesuai dengan tingkatan manajemen dari pengguna informasi tersebut, menghasilkan skor aktual sebesar 136 atau sekitar 90,7 \% dari total skor ideal yang telah ditentukan. Berdasarkan hasil persentase skor aktual untuk item pertanyaan nomor 3 (tiga) dapat disimpulkan bahwa tanggapan responden berada pada kategori sangat baik. Hal ini dapat diartikan bahwa para karyawan PT. Perisai Husada mengetahui bahwa informasi yang digunakan harus sesuai dengan tingkatan manajemen yang diperlukannya.

Berdasarkan ketiga item pernyataan di atas, diperoleh total skor tanggapan responden yang menghasilkan persentase sebesar $91,11 \%$, maka dapat dinilai bahwa tingkat relevansi terhadap kepuasan informasi berada pada kategori sangat baik. Sehingga dapat disimpulkan bahwa tingkat relevansi informasi terhadap kepuasan pemakai sistem informasi PT. Perisai Husada dinilai sangat baik oleh responden. Hal tersebut dilihat dari persentase yang didapat, yaitu sebesar 92,44\% yang berdasarkan analisis Rank-Order Mean termasuk dalam kategori sangat baik (>84\% - 100\%). Besarnya tingkat persentase relevansi informasi terhadap kepuasan pemakai sistem informasi PT. Perisai Husada ini menunjukkan bahwa para responden merasa sangat puas dengan relevansi informasi yang dihasilkan.

\section{Tingkat kualitas informasi Berdasarkan Ketepatan Waktu Informasi}

\section{Tabel 6}

Tingkat Kualitas Informasi Berdasarkan Ketepatan Waktu Informasi

\begin{tabular}{|c|c|c|c|c|c|c|}
\hline $\begin{array}{c}\text { Item } \\
\text { Pernyataan }\end{array}$ & Jawaban & Skor & $\mathbf{F}$ & $\%$ & $\begin{array}{c}\text { Skor } \\
\text { Aktual }\end{array}$ & $\begin{array}{l}\text { Skor } \\
\text { Ideal }\end{array}$ \\
\hline \multirow{5}{*}{4} & Sangat Setuju & 5 & 18 & 60 & 90 & \multirow{5}{*}{150} \\
\hline & Setuju & 4 & 11 & 36,7 & 44 & \\
\hline & Netral & 3 & 1 & 3,3 & 3 & \\
\hline & Tidak Setuju & 2 & 0 & & & \\
\hline & Sangat Tidak Setuju & 1 & 0 & & & \\
\hline \multirow{2}{*}{\multicolumn{5}{|c|}{ Skor Aktual }} & 137 & \\
\hline & & & & & \multicolumn{2}{|l|}{$91,33 \%$} \\
\hline $\begin{array}{c}\text { Item } \\
\text { Pernyataan } \\
\end{array}$ & Jawaban & Skor & $\mathbf{F}$ & $\%$ & $\begin{array}{c}\text { Skor } \\
\text { Aktual } \\
\end{array}$ & $\begin{array}{l}\text { Skor } \\
\text { Ideal }\end{array}$ \\
\hline \multirow[t]{5}{*}{ J } & Sangat Setuju & 5 & 23 & 76,7 & 115 & \multirow{5}{*}{150} \\
\hline & Setuju & 4 & 7 & 23,3 & 28 & \\
\hline & Netral & 3 & 0 & & & \\
\hline & Tidak Setuju & 2 & 0 & & & \\
\hline & Sangat Tidak Setuju & 1 & 0 & & & \\
\hline \multirow{2}{*}{\multicolumn{5}{|c|}{ Skor Aktual }} & 143 & \\
\hline & & & & & \multicolumn{2}{|l|}{$95,33 \%$} \\
\hline & \multicolumn{4}{|c|}{ Total Keseluruhan } & \multirow{2}{*}{\multicolumn{2}{|c|}{\begin{tabular}{|r|r|}
280 & 300 \\
& $93,33 \%$
\end{tabular}}} \\
\hline & \multicolumn{4}{|c|}{$\%$ Total Keseluruhan } & & \\
\hline
\end{tabular}


Hasil tanggapan responden pada item pertanyaan nomor 1 (satu), yaitu bahwa informasi harus dapat dihasilkan secara tepat waktu, menghasilkan skor aktual sebesar 137 atau sekitar 91,33\% dari total skor ideal yang telah ditentukan. Berdasarkan hasil persentase skor aktual untuk item pertanyaan nomor 1 (satu) dapat disimpulkan bahwa tanggapan responden berada pada kategori sangat baik. Hal ini dapat diartikan bahwa para karyawan PT. Perisai Husada menginginkan bahwa informasi yang dihasilkannya harus tersedia tepat waktu.

Hasil tanggapan responden pada item pertanyaan nomor 2 (dua), yaitu bahwa informasi harus memberikan informasi yang up to date, menghasilkan skor aktual sebesar 143 atau sekitar $95,33 \%$ dari total skor ideal yang telah ditentukan. Berdasarkan hasil persentase skor aktual untuk item pertanyaan nomor 2 (dua) dapat disimpulkan bahwa tanggapan responden berada pada kategori sangat baik. Hal ini dapat diartikan bahwa informasi yang diperlukan harus memiliki nilai terkini, sehingga para pengguna informasi tidak mengalami ketinggalan informasi.

Berdasarkan kedua item pernyataan di atas, diperoleh total skor tanggapan responden yang menghasilkan persentase sebesar 93,33\%, maka dapat dinilai bahwa tingkat ketepatan waktu terhadap kepuasan informasi berada pada kategori sangat baik. Sehingga dapat disimpulkan bahwa tingkat ketepatan waktu informasi terhadap kepuasan pemakai sistem informasi PT. Perisai Husada dinilai sangat baik oleh responden. Hal tersebut dilihat dari persentase yang didapat, yaitu sebesar 93,33\% yang berdasarkan analisis Rank-Order Mean termasuk dalam kategori sangat baik ( $>84 \%-100 \%)$. Besarnya tingkat persentase tingkat ketepatan waktu pemberian informasi terhadap kepuasan pemakai sistem informasi PT. Perisai Husada ini menunjukkan bahwa para responden merasa sangat puas dengan tingkat ketepatan waktu informasi yang dihasilkan.

\section{TINGKAT KEPUASAN PEMAKAI SISTEM INFORMASI AKUNTANSI}

Berikut ini adalah analisis mengenai kepuasan pemakai sistem informasi yang diukur dengan menggunakan dimensi isi, keakuratan, bentuk, kemudahan menggunakan, dan ketepatan waktu.

\section{Tingkat Kepuasan Informasi Berdasarkan Dimensi Isi}

Tabel 7

Tingkat Kepuasan Pemakai Sistem Informasi Berdasarkan Dimensi Isi

\begin{tabular}{|c|c|c|c|c|c|c|}
\hline $\begin{array}{c}\text { Item } \\
\text { Pernyataan }\end{array}$ & Jawaban & Skor & $\mathbf{F}$ & $\%$ & $\begin{array}{c}\text { Skor } \\
\text { Aktual } \\
\end{array}$ & $\begin{array}{l}\text { Skor } \\
\text { Ideal }\end{array}$ \\
\hline \multirow{5}{*}{ 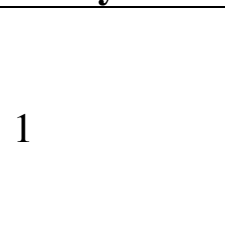 } & Sangat Setuju & 5 & 15 & 50 & 75 & \multirow{5}{*}{150} \\
\hline & Setuju & 4 & 7 & 23,3 & 28 & \\
\hline & Netral & 3 & 6 & 20 & 18 & \\
\hline & Tidak Setuju & 2 & 2 & 6,7 & 4 & \\
\hline & Sangat Tidak Setuju & 1 & 0 & & & \\
\hline \multirow{2}{*}{\multicolumn{5}{|c|}{ Skor Aktual }} & 125 & \\
\hline & & & & & \multicolumn{2}{|l|}{$83,33 \%$} \\
\hline $\begin{array}{c}\text { Item } \\
\text { Pernyataan }\end{array}$ & Jawaban & Skor & $\mathbf{F}$ & $\%$ & $\begin{array}{c}\text { Skor } \\
\text { Aktual }\end{array}$ & $\begin{array}{l}\text { Skor } \\
\text { Ideal }\end{array}$ \\
\hline & Sangat Setuju & 5 & 15 & 50 & 75 & \\
\hline
\end{tabular}




\begin{tabular}{|c|c|c|c|c|c|c|}
\hline \multirow{4}{*}{2} & Setuju & 4 & 7 & 23,3 & 28 & \multirow{4}{*}{150} \\
\hline & Netral & 3 & 6 & 20 & 18 & \\
\hline & Tidak Setuju & 2 & 2 & 6,7 & 4 & \\
\hline & Sangat Tidak Setuju & 1 & 0 & & & \\
\hline & Total & & 30 & & 125 & \\
\hline & \multicolumn{4}{|c|}{ Skor Aktual } & \multicolumn{2}{|l|}{$83,33 \%$} \\
\hline $\begin{array}{c}\text { Item } \\
\text { Pernyataan }\end{array}$ & Jawaban & Skor & $\mathbf{F}$ & $\%$ & $\begin{array}{c}\text { Skor } \\
\text { Aktual }\end{array}$ & $\begin{array}{l}\text { Skor } \\
\text { Ideal }\end{array}$ \\
\hline \multirow{5}{*}{3} & Sangat Setuju & 5 & 15 & 50 & 75 & \multirow{5}{*}{150} \\
\hline & Setuju & 4 & 8 & 26,7 & 32 & \\
\hline & Netral & 3 & 5 & 20 & 15 & \\
\hline & Tidak Setuju & 2 & 2 & 6,7 & 4 & \\
\hline & Sangat Tidak Setuju & 1 & 0 & & & \\
\hline \multirow{2}{*}{\multicolumn{5}{|c|}{ Skor Aktual }} & 126 & \\
\hline & & & & & \multicolumn{2}{|l|}{$84 \%$} \\
\hline & \multicolumn{4}{|c|}{ Total Keseluruhan } & 376 & 450 \\
\hline & \multicolumn{4}{|c|}{$\%$ Total Keseluruhan } & \multicolumn{2}{|c|}{$83,56 \%$} \\
\hline
\end{tabular}

Hasil tanggapan responden pada item pertanyaan nomor 1 (satu), yaitu bahwa kepuasan pengguna sistem informasi untuk dimensi isi informasi telah memberikan informasi yang tepat sesuai dengan yang dibutuhkan responden, menghasilkan skor aktual sebesar 125 atau sekitar 83,33\% dari total skor ideal yang telah ditentukan. Berdasarkan hasil persentase skor aktual untuk item pertanyaan nomor 1 (satu) dapat disimpulkan bahwa tanggapan responden berada pada kategori baik. Hal ini dapat diartikan bahwa para karyawan PT. Perisai Husada telah merasa puas dari sisi isi/content informasi yang dihasilkan.

Hasil tanggapan responden pada item pertanyaan nomor 2 (dua), yaitu bahwa kepuasan pengguna sistem informasi untuk dimensi isi informasi telah menghasilkan laporan yang sesuai dengan yang dibutuhkan responden, menghasilkan skor aktual sebesar 125 atau sekitar $83,33 \%$ dari total skor ideal yang telah ditentukan. Berdasarkan hasil persentase skor aktual untuk item pertanyaan nomor 2 (dua) dapat disimpulkan bahwa tanggapan responden berada pada kategori baik. Hal ini dapat diartikan bahwa para karyawan PT. Perisai Husada telah merasa puas dari sisi isi/content informasi yang dihasilkan, yaitu laporan yang dihasilkan telah sesuai dengan yang dibutuhkan.

Hasil tanggapan responden pada item pertanyaan nomor 3 (tiga), yaitu bahwa kepuasan pengguna sistem informasi untuk dimensi isi informasi telah memberikan informasi yang memadai, menghasilkan skor aktual sebesar 126 atau sekitar $84 \%$ dari total skor ideal yang telah ditentukan. Berdasarkan hasil persentase skor aktual untuk item pertanyaan nomor 3 (tiga) dapat disimpulkan bahwa tanggapan responden berada pada kategori sangat baik. Hal ini dapat diartikan bahwa para karyawan PT. Perisai Husada telah merasa puas dari sisi isi/content informasi yang dihasilkan telah memberikan informasi yang memadai.

Berdasarkan ketiga item pernyataan di atas, diperoleh total skor tanggapan responden yang menghasilkan persentase sebesar 83,56\%, maka dapat dinilai bahwa sistem informasi dari dimensi isi berada pada kategori baik. Sehingga dapat disimpulkan bahwa tingkat kepuasan responden dari dimensi isi di PT. Perisai Husada dinilai baik oleh responden. Hal tersebut dilihat dari persentase yang didapat, yaitu sebesar $83,56 \%$ yang berdasarkan analisis Rank- 
Order Mean termasuk dalam kategori baik (68\% - >84\%). Besarnya tingkat persentase kepuasan pemakai dari dimensi isi/content PT. Perisai Husada ini menunjukkan bahwa para responden merasa puas dengan isi dari informasi yang dihasilkan.

\section{Tingkat Kepuasan Informasi Berdasarkan Dimensi Keakuratan}

\section{Tabel 8}

Tingkat Kepuasan Pemakai Sistem Informasi Berdasarkan Dimensi Keakuratan

\begin{tabular}{|c|c|c|c|c|c|c|}
\hline $\begin{array}{c}\text { Item } \\
\text { Pernyataan }\end{array}$ & Jawaban & Skor & $\mathbf{F}$ & $\%$ & $\begin{array}{c}\text { Skor } \\
\text { Aktual }\end{array}$ & $\begin{array}{l}\text { Skor } \\
\text { Ideal }\end{array}$ \\
\hline \multirow[t]{5}{*}{ J } & Sangat Setuju & 5 & 15 & 50 & 75 & \multirow{5}{*}{150} \\
\hline & Setuju & 4 & 7 & 23,3 & 28 & \\
\hline & Netral & 3 & 6 & 20 & 18 & \\
\hline & Tidak Setuju & 2 & 2 & 6,7 & 4 & \\
\hline & Sangat Tidak Setuju & 1 & 0 & & & \\
\hline \multirow{2}{*}{\multicolumn{5}{|c|}{ Skor Aktual }} & 125 & \\
\hline & & & & & \multicolumn{2}{|l|}{$83,33 \%$} \\
\hline $\begin{array}{c}\text { Item } \\
\text { Pernyataan }\end{array}$ & Jawaban & Skor & $\mathbf{F}$ & $\%$ & $\begin{array}{c}\text { Skor } \\
\text { Aktual }\end{array}$ & $\begin{array}{l}\text { Skor } \\
\text { Ideal }\end{array}$ \\
\hline \multirow{5}{*}{ - } & Sangat Setuju & 5 & 10 & 33,3 & 50 & \multirow{5}{*}{150} \\
\hline & Setuju & 4 & 12 & 40 & 48 & \\
\hline & Netral & 3 & 6 & 20 & 18 & \\
\hline & Tidak Setuju & 2 & 2 & 6,7 & 4 & \\
\hline & Sangat Tidak Setuju & 1 & 0 & & & \\
\hline \multirow{2}{*}{\multicolumn{5}{|c|}{ Skor Aktual }} & 120 & \\
\hline & & & & & \multicolumn{2}{|l|}{$80 \%$} \\
\hline & \multicolumn{4}{|c|}{ Total Keseluruhan } & 245 & \\
\hline & \multicolumn{4}{|c|}{$\%$ Total Keseluruhan } & \multicolumn{2}{|c|}{$81,67 \%$} \\
\hline
\end{tabular}

Hasil tanggapan responden pada item pertanyaan nomor 1 (satu), yaitu bahwa kepuasan pengguna sistem informasi untuk keakuratan informasi telah memberikan informasi yang tepat sesuai dengan yang dibutuhkan responden, menghasilkan skor aktual sebesar 125 atau sekitar 83,33\% dari total skor ideal yang telah ditentukan. Berdasarkan hasil persentase skor aktual untuk item pertanyaan nomor 1 (satu) dapat disimpulkan bahwa tanggapan responden berada pada kategori baik. Hal ini dapat diartikan bahwa para karyawan PT. Perisai Husada telah merasa puas dari sisi isi/content informasi yang dihasilkan.

Hasil tanggapan responden pada item pertanyaan nomor 2 (dua), yaitu bahwa kepuasan pengguna sistem informasi untuk dimensi keakuratan, para responden telah merasa puas, menghasilkan skor aktual sebesar 120 atau sekitar $80 \%$ dari total skor ideal yang telah ditentukan. Berdasarkan hasil persentase skor aktual untuk item pertanyaan nomor 2 (dua) dapat disimpulkan bahwa tanggapan responden berada pada kategori baik. Hal ini dapat diartikan bahwa para karyawan PT. Perisai Husada telah merasa puas dari sisi akuratnya sistem informasi yang digunakan.

Berdasarkan kedua item pernyataan di atas, diperoleh total skor tanggapan responden yang menghasilkan persentase sebesar $81,67 \%$, maka dapat dinilai bahwa sistem informasi dari 
dimensi keakuratan berada pada kategori baik. Sehingga dapat disimpulkan bahwa tingkat kepuasan responden dari dimensi keakuratan ini di PT. Perisai Husada dinilai baik oleh responden. Hal tersebut dilihat dari persentase yang didapat, yaitu sebesar $81,67 \%$ yang berdasarkan analisis Rank-Order Mean termasuk dalam kategori baik (68\% - >84\%). Besarnya tingkat persentase kepuasan pemakai dari dimensi keakuratan di PT. Perisai Husada ini menunjukkan bahwa para responden merasa puas dengan tingkat keakuratan informasi yang dihasilkan.

\section{Tingkat Kepuasan Informasi Berdasarkan Dimensi Bentuk}

\section{Tabel 9}

Tingkat Kepuasan Pemakai Sistem Informasi Berdasarkan Dimensi Bentuk

\begin{tabular}{|c|c|c|c|c|c|c|}
\hline $\begin{array}{c}\text { Item } \\
\text { Pernyataan } \\
\end{array}$ & Jawaban & Skor & $\mathbf{F}$ & $\%$ & $\begin{array}{c}\text { Skor } \\
\text { Aktual }\end{array}$ & $\begin{array}{l}\text { Skor } \\
\text { Ideal }\end{array}$ \\
\hline \multirow{5}{*}{1} & Sangat Setuju & 5 & 13 & 43,3 & 65 & \multirow{5}{*}{150} \\
\hline & Setuju & 4 & 13 & 43,3 & 52 & \\
\hline & Netral & 3 & 2 & 6,7 & 6 & \\
\hline & Tidak Setuju & 2 & 2 & 6,7 & 4 & \\
\hline & Sangat Tidak Setuju & 1 & 0 & & & \\
\hline \multirow{2}{*}{\multicolumn{5}{|c|}{ Skor Aktual }} & 127 & \\
\hline & & & & & \multicolumn{2}{|l|}{$84,7 \%$} \\
\hline $\begin{array}{c}\text { Item } \\
\text { Pernyataan }\end{array}$ & Jawaban & Skor & $\mathbf{F}$ & $\%$ & $\begin{array}{c}\text { Skor } \\
\text { Aktual }\end{array}$ & $\begin{array}{l}\text { Skor } \\
\text { Ideal }\end{array}$ \\
\hline \multirow[t]{5}{*}{ J } & Sangat Setuju & 5 & 15 & 50 & 75 & \multirow{5}{*}{150} \\
\hline & Setuju & 4 & 9 & 30 & 36 & \\
\hline & Netral & 3 & 4 & 13,3 & 12 & \\
\hline & Tidak Setuju & 2 & 2 & 6,7 & 4 & \\
\hline & Sangat Tidak Setuju & 1 & 0 & & & \\
\hline \multirow{2}{*}{\multicolumn{5}{|c|}{ Skor Aktual }} & 127 & \\
\hline & & & & & \multicolumn{2}{|l|}{$84,7 \%$} \\
\hline \multicolumn{5}{|c|}{ Total Keseluruhan } & 254 & 300 \\
\hline \multicolumn{5}{|c|}{$\%$ Total Keseluruhan } & \multicolumn{2}{|c|}{$84,67 \%$} \\
\hline
\end{tabular}

Hasil tanggapan responden pada item pertanyaan nomor 1 (satu), yaitu bahwa kepuasan pengguna sistem informasi untuk dimensi bentuk telah memiliki bentuk / format laporan yang sesuai dengan yang diperlukan, menghasilkan skor aktual sebesar 127 atau sekitar 84,7\% dari total skor ideal yang telah ditentukan. Berdasarkan hasil persentase skor aktual untuk item pertanyaan nomor 1 (satu) dapat disimpulkan bahwa tanggapan responden berada pada kategori baik. Hal ini dapat diartikan bahwa para karyawan PT. Perisai Husada telah merasa puas atau merasa informasi yang dihasilkan dapat menghasilkan bentuk / format yang dibutuhkannya.

Hasil tanggapan responden pada item pertanyaan nomor 2 (dua), yaitu bahwa kepuasan pengguna sistem informasi untuk dimensi bentuk sudah sangat mudah dimengerti , menghasilkan skor aktual sebesar 127 atau sekitar 84,7\% dari total skor ideal yang telah ditentukan. Berdasarkan hasil persentase skor aktual untuk item pertanyaan nomor 2 (dua) dapat disimpulkan bahwa tanggapan responden berada pada kategori baik. Hal ini dapat 
diartikan bahwa para karyawan PT. Perisai Husada telah merasa puas dari sisi bentuk yang digunakan, sehingga bisa lebih mudah dimengerti.

Berdasarkan kedua item pernyataan di atas, diperoleh total skor tanggapan responden yang menghasilkan persentase sebesar 84,67\%, maka dapat dinilai bahwa sistem informasi dari dimensi keakuratan berada pada kategori sangat baik. Sehingga dapat disimpulkan bahwa tingkat kepuasan responden dari dimensi keakuratan ini di PT. Perisai Husada dinilai sangat baik oleh responden. Hal tersebut dilihat dari persentase yang didapat, yaitu sebesar $84,67 \%$ yang berdasarkan analisis Rank-Order Mean termasuk dalam kategori sangat baik (84\% > $100 \%$ ). Besarnya tingkat persentase kepuasan pemakai dari dimensi keakuratan di PT. Perisai Husada ini menunjukkan bahwa para responden merasa puas dengan format bentuk informasi yang disajikan sehingga menjadi lebih mudah dimengerti.

\section{Tingkat Kepuasan Informasi Berdasarkan Dimensi Kemudahan Penggunaan}

\section{Tabel 10}

\section{Tingkat Kepuasan Pemakai Sistem Informasi Berdasarkan Dimensi Kemudahan} Penggunaan

\begin{tabular}{|c|c|c|c|c|c|c|}
\hline $\begin{array}{c}\text { Item } \\
\text { Pernyataan }\end{array}$ & Jawaban & Skor & $\mathbf{F}$ & $\%$ & $\begin{array}{c}\text { Skor } \\
\text { Aktual }\end{array}$ & $\begin{array}{l}\text { Skor } \\
\text { Ideal }\end{array}$ \\
\hline \multirow[t]{5}{*}{ J } & Sangat Setuju & 5 & 10 & 33,3 & 50 & \multirow{5}{*}{150} \\
\hline & Setuju & 4 & 15 & 50 & 60 & \\
\hline & Netral & 3 & 5 & 16,7 & 15 & \\
\hline & Tidak Setuju & 2 & 0 & & & \\
\hline & Sangat Tidak Setuju & 1 & 0 & & & \\
\hline \multirow{2}{*}{\multicolumn{5}{|c|}{ Skor Aktual }} & 125 & \\
\hline & & & & & \multicolumn{2}{|l|}{$83,33 \%$} \\
\hline $\begin{array}{c}\text { Item } \\
\text { Pernyataan }\end{array}$ & Jawaban & Skor & $\mathbf{F}$ & $\%$ & $\begin{array}{c}\text { Skor } \\
\text { Aktual }\end{array}$ & $\begin{array}{l}\text { Skor } \\
\text { Ideal }\end{array}$ \\
\hline \multirow{5}{*}{ - } & Sangat Setuju & 5 & 15 & 50 & 75 & \multirow{5}{*}{150} \\
\hline & Setuju & 4 & 12 & 40 & 48 & \\
\hline & Netral & 3 & 3 & 10 & 9 & \\
\hline & Tidak Setuju & 2 & 2 & & & \\
\hline & Sangat Tidak Setuju & 1 & 0 & & & \\
\hline \multirow{2}{*}{\multicolumn{5}{|c|}{ Skor Aktual }} & 132 & \\
\hline & & & & & \multicolumn{2}{|l|}{$88 \%$} \\
\hline & \multicolumn{4}{|c|}{ Total Keseluruhan } & 257 & \\
\hline & \multicolumn{4}{|c|}{$\%$ Total Keseluruhan } & \multicolumn{2}{|c|}{$85,67 \%$} \\
\hline
\end{tabular}

Hasil tanggapan responden pada item pertanyaan nomor 1 (satu), yaitu bahwa kepuasan pengguna sistem informasi untuk dimensi kemudahan dari penggunaan sistem informasi, menghasilkan skor aktual sebesar 125 atau sekitar 83,3\% dari total skor ideal yang telah ditentukan. Berdasarkan hasil persentase skor aktual untuk item pertanyaan nomor 1 (satu) dapat disimpulkan bahwa tanggapan responden berada pada kategori baik. Hal ini dapat diartikan bahwa para karyawan PT. Perisai Husada telah merasa puas atau merasa informasi yang dihasilkan mudah digunakan. 
Hasil tanggapan responden pada item pertanyaan nomor 2 (dua), yaitu bahwa kepuasan pengguna sistem informasi untuk dimensi kemudahan, yaitu dari sisi tampilannya yang mudah dimengerti, menghasilkan skor aktual sebesar 132 atau sekitar $88 \%$ dari total skor ideal yang telah ditentukan. Berdasarkan hasil persentase skor aktual untuk item pertanyaan nomor 2 (dua) dapat disimpulkan bahwa tanggapan responden berada pada kategori sangat baik. Hal ini dapat diartikan bahwa para karyawan PT. Perisai Husada telah merasa puas karena merasa sistem informasi yang ditampilkan mudah dimengerti (user friendly).

Berdasarkan kedua item pernyataan di atas, diperoleh total skor tanggapan responden yang menghasilkan persentase sebesar 85,67\%, maka dapat dinilai bahwa sistem informasi dari dimensi kemudahan dalam penggunaannya berada pada kategori sangat baik. Sehingga dapat disimpulkan bahwa tingkat kepuasan responden dari dimensi kemudahan dalam penggunaannya ini di PT. Perisai Husada dinilai sangat baik oleh responden. Hal tersebut dilihat dari persentase yang didapat, yaitu sebesar $85,67 \%$ yang berdasarkan analisis RankOrder Mean termasuk dalam kategori sangat baik $(84 \%>100 \%)$. Besarnya tingkat persentase kepuasan pemakai dari dimensi kemudahan dalam penggunaannya di PT. Perisai Husada ini menunjukkan bahwa para responden merasa puas dengan tampilan informasi yang disajikan sehingga menjadi lebih mudah dimengerti.

\section{Tingkat Kepuasan Informasi Berdasarkan Dimensi Ketepatan Waktu}

Tabel 11

\section{Tingkat Kepuasan Pemakai Sistem Informasi Berdasarkan Dimensi Ketepatan Waktu}

\begin{tabular}{|c|c|c|c|c|c|c|}
\hline $\begin{array}{c}\text { Item } \\
\text { Pernyataan }\end{array}$ & Jawaban & Skor & $\mathbf{F}$ & $\%$ & $\begin{array}{c}\text { Skor } \\
\text { Aktual }\end{array}$ & $\begin{array}{l}\text { Skor } \\
\text { Ideal }\end{array}$ \\
\hline \multirow[t]{5}{*}{ (1) } & Sangat Setuju & 5 & 14 & 46,7 & 70 & \multirow{5}{*}{150} \\
\hline & Setuju & 4 & 6 & 20 & 24 & \\
\hline & Netral & 3 & 8 & 26,7 & 24 & \\
\hline & Tidak Setuju & 2 & 2 & 6,6 & 4 & \\
\hline & Sangat Tidak Setuju & 1 & 0 & & & \\
\hline \multirow{2}{*}{\multicolumn{5}{|c|}{ Skor Aktual }} & 122 & \\
\hline & & & & & \multicolumn{2}{|l|}{$81,33 \%$} \\
\hline $\begin{array}{c}\text { Item } \\
\text { Pernyataan }\end{array}$ & Jawaban & Skor & $\mathbf{F}$ & $\%$ & $\begin{array}{c}\text { Skor } \\
\text { Aktual }\end{array}$ & $\begin{array}{l}\text { Skor } \\
\text { Ideal }\end{array}$ \\
\hline \multirow{5}{*}{ 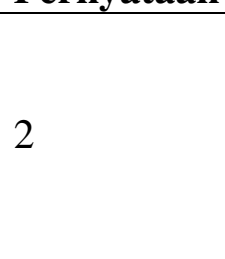 } & Sangat Setuju & 5 & 15 & 50 & 75 & \multirow{5}{*}{150} \\
\hline & Setuju & 4 & 8 & 26,7 & 32 & \\
\hline & Netral & 3 & 5 & 16,7 & 15 & \\
\hline & Tidak Setuju & 2 & 2 & 6,6 & 4 & \\
\hline & Sangat Tidak Setuju & 1 & 0 & & & \\
\hline \multirow{2}{*}{\multicolumn{5}{|c|}{ Skor Aktual }} & 126 & \\
\hline & & & & & \multicolumn{2}{|l|}{$84 \%$} \\
\hline & \multicolumn{4}{|c|}{ Total Keseluruhan } & 248 & \\
\hline & \multicolumn{4}{|c|}{$\%$ Total Keseluruhan } & \multicolumn{2}{|c|}{$82,67 \%$} \\
\hline
\end{tabular}

Hasil tanggapan responden pada item pertanyaan nomor 1 (satu), yaitu bahwa kepuasan pengguna sistem informasi untuk dimensi ketepatan yang digunakan dalam sistem informasi di PT. Perisai Husada ini, menghasilkan informasi yang dibutuhkan secara tepat waktu, 
dengan skor aktual sebesar 122 atau sekitar $81,33 \%$ dari total skor ideal yang telah ditentukan. Berdasarkan hasil persentase skor aktual untuk item pertanyaan nomor 1 (satu) dapat disimpulkan bahwa tanggapan responden berada pada kategori baik. Hal ini dapat diartikan bahwa para karyawan PT. Perisai Husada telah merasa puas karena informasi yang dihasilkan tepat waktu.

Hasil tanggapan responden pada item pertanyaan nomor 2 (dua), yaitu bahwa kepuasan pengguna sistem informasi untuk dimensi ketepatan, yaitu dari sisi bahwa sistem informasi tersebut telah memberikan informasi yang terkini (up to date), menghasilkan skor aktual sebesar 126 atau sekitar $84 \%$ dari total skor ideal yang telah ditentukan. Berdasarkan hasil persentase skor aktual untuk item pertanyaan nomor 2 (dua) dapat disimpulkan bahwa tanggapan responden berada pada kategori sangat baik. Hal ini dapat diartikan bahwa para karyawan PT. Perisai Husada telah merasa puas karena merasa sistem informasi yang diberikan adalah informasi terkini.

Berdasarkan kedua item pernyataan di atas, diperoleh total skor tanggapan responden yang menghasilkan persentase sebesar $82,67 \%$, maka dapat dinilai bahwa sistem informasi dari dimensi ketepatan waktu dari sistem informasi akuntansi berada pada kategori baik. Sehingga dapat disimpulkan bahwa tingkat kepuasan responden dari dimensi ketepatan waktu dalam penggunaannya ini di PT. Perisai Husada dinilai baik oleh responden. Hal tersebut dilihat dari persentase yang didapat, yaitu sebesar $82,67 \%$ yang berdasarkan analisis RankOrder Mean termasuk dalam kategori sangat baik $(68 \%-84 \%)$. Besarnya tingkat persentase kepuasan pemakai dari dimensi ketepatan waktu dari sistem informasi akuntansi di PT. Perisai Husada ini menunjukkan bahwa para responden merasa puas dengan ketepatan waktu dan informasi yang diberikan adalah informasi yang terkini.

\section{Uji Validitas}

Berikut hasil perhitungan uji validitas untuk setiap pertanyaan dalam quesioner

Tabel 12

\section{Hasil Uji Validitas}

\begin{tabular}{|c|c|c|c|c|c|}
\hline $\begin{array}{c}\text { Butir } \\
\text { Pertanyaan }\end{array}$ & $\begin{array}{c}\text { Nilai } \\
\mathrm{R} \\
\text { hitung }\end{array}$ & $\begin{array}{c}\text { Kesimpulan } \\
\text { Mengunakan } \\
\text { SPSS } \\
\text { Versi 20 }\end{array}$ & $\begin{array}{c}\text { Butir } \\
\text { Pertanyaan }\end{array}$ & $\begin{array}{c}\text { Nilai R } \\
\text { hitung }\end{array}$ & $\begin{array}{c}\text { Kesimpulan } \\
\text { Mengunakan } \\
\text { SPSS } \\
\text { Versi 20 }\end{array}$ \\
\hline 1 & 0.906 & Valid & 11 & 0.996 & Valid \\
\hline 2 & 0.871 & Valid & 12 & 0.955 & Valid \\
\hline 3 & 0.896 & Valid & 13 & 0.975 & Valid \\
\hline 4 & 0.511 & Valid & 14 & 0.950 & Valid \\
\hline 5 & 0.992 & Valid & 15 & 0.957 & Valid \\
\hline 6 & 0.982 & Valid & 16 & 0.952 & Valid \\
\hline 7 & 0.976 & Valid & 17 & 0.938 & Valid \\
\hline 8 & 0.834 & Valid & 18 & 0.991 & Valid \\
\hline 9 & 0.998 & Valid & 19 & 0.979 & Valid \\
\hline 10 & 0.998 & Valid & & & \\
\hline
\end{tabular}




\section{Uji Reliabilitas}

Berikut hasil perhituangan uji reliabilitas untuk setiap pertanyaan dalam quesioner

\section{Tabel 13}

\section{Hasil Uji Reliabilitas}

\begin{tabular}{|c|c|}
\hline $\begin{array}{c}\text { Cronbach's } \\
\text { Alpha }\end{array}$ & $\begin{array}{c}\text { Kesimpul } \\
\text { an }\end{array}$ \\
\hline .969 & Reliabel \\
\hline
\end{tabular}

\section{Analisis Korelasi}

Tabel 14

Analisis Korelasi

\begin{tabular}{|c|c|c|c|c|c|c|}
\hline & & & $\begin{array}{l}\text { Akurasi } \\
\text { Informasi }\end{array}$ & $\begin{array}{l}\text { Ketepatan } \\
\text { Waktu }\end{array}$ & $\begin{array}{l}\text { Relevansi } \\
\text { Informasi }\end{array}$ & $\begin{array}{l}\text { Kepuasan } \\
\text { pemakai } \\
\text { sistem } \\
\text { informasi }\end{array}$ \\
\hline \multirow{12}{*}{ Spearman's rho } & \multirow{3}{*}{$\begin{array}{l}\text { Akurasi } \\
\text { Informasi }\end{array}$} & Correlation Coefficient & 1.000 & $.638^{* * 4}$ & $.939^{* * 3}$ & $.770^{* * *}$ \\
\hline & & Sig. (2-tailed) & & .000 & .000 & .000 \\
\hline & & $\mathrm{N}$ & 30 & 30 & 30 & 30 \\
\hline & \multirow{3}{*}{$\begin{array}{l}\text { Ketepatan } \\
\text { Waktu }\end{array}$} & Correlation Coefficient & $.638^{* *}$ & 1.000 & $.550^{* *}$ & $.367^{*}$ \\
\hline & & Sig. (2-tailed) & .000 & & .002 & .046 \\
\hline & & $\mathrm{N}$ & 30 & 30 & 30 & 30 \\
\hline & \multirow{3}{*}{$\begin{array}{l}\text { Relevansi } \\
\text { Informasi }\end{array}$} & Correlation Coefficient & $.939^{* *}$ & $.550^{* *}$ & 1.000 & $.768^{* *}$ \\
\hline & & Sig. (2-tailed) & .000 & .002 & & .000 \\
\hline & & $\mathrm{N}$ & 30 & 30 & 30 & 30 \\
\hline & \multirow{3}{*}{$\begin{array}{l}\text { Kepuasan } \\
\text { pemakai } \\
\text { sistem } \\
\text { informasi }\end{array}$} & Correlation Coefficient & $.770^{* *}$ & $.367^{*}$ & $.768^{* *}$ & 1.000 \\
\hline & & Sig. (2-tailed) & .000 & .046 & .000 & \\
\hline & & $\mathrm{N}$ & 30 & 30 & 30 & 30 \\
\hline
\end{tabular}

Berdasarkan hasil analisis korelasi dan dibandingkan dengan tabel 3 mengenai interpretasi nilai koefisien korelasi maka dapat diketahui hubungan korelasi antara varibel $\mathrm{x}$ dan $\mathrm{y}$ sebagai berikut:

1. Hubungan akurasi informasi terhadap kepuasan pemakai sistem informasi memiliki nilai 0.770 berada pada rentang interpretasi nilai koefisen korelasi antara $0.60-0.799$ yang berarti memiliki peranan yang kuat.

2. Hubungan ketepatan waktu informasi terhadap kepuasan pemakai sistem informasi memiliki nilai 0.367 berada pada rentang interpretasi nilai koefisen korelasi antara $0.20-0.399$ yang berarti memiliki peranan yang rendah.

3. Hubungan relevansi informasi terhadap kepuasan pemakai sistem informasi memiliki nilai 0.768 berada pada rentang interpretasi nilai koefisen korelasi antara $0.60-0.799$ yang berarti memiliki peranan yang kuat.

\section{Pengujian Hipotesis}

Pengujian dari hasil perhitungan koefisien korelasi variabel akurasi informasi dengan menggunakan koefisien korelasi rank spearman $(\rho)$ hitung diperoleh nilai 0,770 dengan nilai 
$\alpha=5 \%$ dan $\mathrm{N}=30$ diperoleh rho $(\rho)$ tabel 0,362 . Berdasarkan hasil perhitungan tersebut dapat disimpulkan bahwa $\rho$ hitung $0,770>\rho$ tabel 0,362 sehingga Ho ditolak dan Ha dapat diterima. Hal ini dapat menjelaskan bahwa terdapat peranan antara akurasi informasi terhadap kepuasan pemakai sistem informasi.

Pengujian dari hasil perhitungan koefisien korelasi variabel ketepatan waktu informasi dengan menggunakan koefisien korelasi rank spearman $(\rho)$ hitung diperoleh nilai 0,367 dengan nilai $\alpha=5 \%$ dan $\mathrm{N}=30$ diperoleh rho $(\rho)$ tabel 0,362 . Berdasarkan hasil perhitungan tersebut dapat disimpulkan bahwa $\rho$ hitung $0,367>\rho$ tabel 0,362 sehingga Ho ditolak dan Ha dapat diterima. Hal ini dapat menjelaskan bahwa terdapat peranan antara ketepatan waktu informasi terhadap kepuasan pemakai sistem informasi.

Pengujian dari hasil perhitungan koefisien korelasi variabel relevansi informasi dengan menggunakan koefisien korelasi rank spearman $(\rho)$ hitung diperoleh nilai 0,768 dengan nilai $\alpha=5 \%$ dan $\mathrm{N}=30$ diperoleh rho $(\rho)$ tabel 0,362 . Berdasarkan hasil perhitungan tersebut dapat disimpulkan bahwa $\rho$ hitung 0,768 > $\rho$ tabel 0,362 sehingga Ho ditolak dan Ha dapat diterima. Hal ini dapat menjelaskan bahwa terdapat peranan antara relevansi informasi terhadap kepuasan pemakai sistem informasi.

\section{SIMPULAN}

Penelitian ini merupakan penelitian studi kasus pada PT Perisai Husada, hasil penelitian ini menunjukan bahwa :

1. Hubungan akurasi informasi terhadap kepuasan pemakai sistem informasi memiliki peranan yang kuat, hal ini dapat diartikan bahwa para pemakai sistem informasi akuntansi di PT. Perisai Husada sudah mengerti akan pentingnya keakuratan dari informasi yang ada, sehingga pemakai sistem informasi ingin informasi yang didapat adalah informasi yang akurat atau informasi yang terbaru.

2. Hubungan ketepatan waktu informasi terhadap kepuasan pemakai sistem informasi memiliki peranan yang rendah, hal ini dapat diartikan bahwa pemakai sistem informasi akuntansi di PT. Perisai Husada masih mengabaikan tingkat ketepatan waktu dari informasi yang diberikan, para pemakai sistem informasi masih belum mementingkan ketepatan waktu dari informasi yang ada, factor terpentingnya adalah walaupun mereka lambat mendapatkan informasi tidak jadi masalah, yang penting mereka akan mendapatkan informasi tersebut walaupun waktunya terlambat.

3. Hubungan relevansi informasi terhadap kepuasan pemakai sistem informasi memiliki peranan yang kuat, hal ini dapat diartikan bahwa pemakai sistem informasi akuntansi di PT. Perisai Husada mementingkan tingkat relevansi dari informasi yang diberikan. Jadi informasi yang diperlukan oleh pemakai sistem informasi tersebut hanyalah yang sesuai dengan yang apa mereka perlukan saja.

\section{SARAN}

\section{Bagi Peneliti Selanjutnya}

Peneliti selanjutnya disarankan untuk menambah sampel, karena mengingat jumlah sampel dalam penelitian ini hanya 30 orang responden 


\section{Bagi Perusahaan}

PT. Perisai Husada dapat memfokuskan aspek keakuratan dan relevansi dari informasi yang diberikan bagi pemakai sistem informasi di perusahaan tersebut, karena dari hasil penelitian yang ada, pemakai sistem informasi tidak begitu memperhatikan ketepatan waktu dari informasi yang diberikan, sehingga para pemakai sistem informasi di PT. Perisai Husada ini lebih mementingkan keakuratan dan relevansinya dari suatu informasi daripada ketepatan waktunya. 


\section{DAFTAR PUSTAKA}

Azhar susanto, Sistem Informasi Akuntansi. Bandung 2005

Ghozali, Imam. (2011). Aplikasi Analisis Multivariate dengan Program IBM SPSS 19 (Edisi 5). Semarang: Universitas Diponegoro.

Gohmann, S.E., Robert M., Barker, David F. F., and Fian G. (2005). Sales Force Automation, Perceived Information Accuracy, and User Satisfaction. Journal of Business \& Industrial Marketing.

Hall, J. A. (2007). Sistem Informasi Akuntansi. Jakarta: Salemba Empat.

Indriantoro, N., dan B. Supomo. (2009). Metodologi Penelitian BisAkuntansi \& Manajemen (Edisi 1). Yogyakarta: BPFE.

Jogiyanto,Teknologi Sistem Informasi, Yogyakarta 2008

Kustono, A. S. (2009). Pengaruh Kualitas Sistem InfoKepuasan Langganan dalam Pengembangan SisAkuntansi. Jurnal Ekonomi Akuntansi dan Organisasi.

Kotler. Manajemen Pemasaran, Jakarta 2007

Krismiaji. (2010). Sistem Informasi Akuntansi. YogyakarYKPN.

Makhbud. Analisis Pengaruh Akurasi, Ketepatan Waktu, dan Relevansi Informasi Terhadap Kepuasan Pemakai Sistem Informasi di PT Telkom Area IV Jateng.

Mulyadi ,Sistem Informasi Akuntansi, Yogyakarta 2010

Romney. Accounting System Information, New York 2000

Sugiyono. (2012). MetoBandung: Alfabeta. Sugiyono. (2012). Metode Penelitian Kuantitatif Kualitatif dan R\&D. Bandung: Alfabeta.

Zunaidi, Waluyo, dan Agustini. (2011). Analisis Pengaruh Akurasi, Ketepatan Waktu, dan Relevansi Informasi terhadap Kepuasan Pemakai Sistem Informasi Atemis on Web di PT Telkom MSC Area IV Jawa Tengah dan DIY. Jurnal Seminar Nasional Teknologi Informasi dan Komunikasi Terapan. 